\title{
Sella landmark variability and its effect on the Angles SNA and SNB: a comparative study
}

\author{
Variabilidade do ponto Sela e seu efeito em ângulos SNA e SNB: um estudo comparativo
}

\author{
Ana Reis DURÃO' \\ Aline Rose Cantarelli MOROSOLLI \\ Cláudia Camila DIAS ${ }^{1}$ \\ Afonso P FERREIRA ${ }^{1}$ \\ Reinhilde JACOBS ${ }^{3}$
}

\section{ABSTRACT}

\section{Objective}

To determine intra- and inter-observer precision in Sella (S), Nasion (N), point A and B identification. Additionally, to determine how it can interfere with angular measurements of SNA and SNB by orthodontists and dentomaxillofacial radiologists.

\section{Methods}

Twenty digital lateral cephalometric radiographs were evaluated by five orthodontists and five dentomaxillofacial radiologists.

\section{Results}

Differences in linear and angular measuremts were assessed. Intra- and inter-observer agreement was evaluated. Intra- and inter-observer reproducibility of the horizontal and vertical components of the S landmark identification (ICC: 0.75/0.90). Orthodontists tended to produce larger SNA $\left(-0.18^{\circ}\right)$, while SNB angle had a tendency to be smaller $\left(0.55^{\circ}\right)$. In general, SNA angle was smaller (DMFRs: $-0.308^{\circ}$ and orthodontists: $-0.092^{\circ}$ ), and SNB presented with larger values (DMFR: $0.078^{\circ}$ and orthodontists: $-0.074^{\circ}$ ).

\section{Conclusion}

Identification of the Sella landmark revealed a better agreement amongst dentomaxillofacial radiologists. Orthodontists, however, showed a larger variability in S identification and, consequently, the SNA and SNB angles drifted significantly.

Indexing terms: Cephalometry. Comparative study. Orthodontics.

\section{RESUMO}

\section{Objetivo}

Determinar a precisão intra e inter-observador na identificação dos pontos Sella (S), Násio (N), A e B. Também, verificar como a identificação dos pontos pode interferir nas medições angulares de SNA e SNB por ortodontistas e radiologistas odontológicos.

\section{Métodos}

Vinte telerradiografias laterais digitais foram avaliadas por cinco ortodontistas e cinco radiologistas odontológicos. Diferenças de medidas lineares e angulares foram avaliadas.

\section{Resultados}

Concordância intra e inter-observador foi avaliada e a reprodutibilidade intra e inter-observador dos componentes horizontais e verticais da identificação S marco (ICC: 0,75 / 0,90). Ortodontistas tenderam a produzir maior valor para SNA $\left(-0.18^{\circ}\right)$, enquanto que para o ângulo SNB houve tendência a dimininuição do valor $\left(0.55^{\circ}\right)$. Em geral, os valores obtidos para o ângulo SNA foram menores (radiologistas: $-0.308^{\circ}$ e ortodontistas: $-0.092^{\circ}$ ) e SNB apresentados com valores maiores (radiologistas: $-0.074^{\circ}$ : $0.078^{\circ}$ e ortodontistas). Concordância intra e inter-observador foi avaliada e a reprodutibilidade intra e inter-observador dos componentes horizontais e verticais da identificação $S$ marco (ICC: $0,75 / 0,90)$. Ortodontistas tenderam a produzir maior valor para SNA $\left(-0.18^{\circ}\right)$, enquanto que para o ângulo SNB houve tendência a dimininuição do valor $\left(0.55^{\circ}\right)$. Em geral, os valores obtidos para o ângulo SNA foram menores (radiologistas: $-0.308^{\circ}$ e ortodontistas: $-0.092^{\circ}$ ) e SNB apresentados com valores maiores (radiologistas: $-0.074^{\circ}: 0.078^{\circ}$ e ortodontistas).

\section{Conclusão}

A identificação do ponto Sella revelou uma melhor concordância entre os radiologistas odontológicos. Ortodontistas, no entanto, mostraram uma maior variabilidade na identificação do ponto S e, consequentemente, os ângulos SNA e SNB variaram significativamente. A identificação do ponto Sella revelou uma melhor concordância entre os radiologistas odontológicos. Ortodontistas, no entanto, mostraram uma maior variabilidade na identificação do ponto S e, consequentemente, os ângulos SNA e SNB variaram significativamente.

Termos de indexação: Circunferência craniana. Estudo comparativo. Ortodontia.

\footnotetext{
${ }^{1}$ Universidade do Porto, Faculdade de Medicina Dentária, Departamento de Radiologia Odontológica. Praça Gomes Teixeira, 4099-002 Porto, Portugal. Correspondência para / Correspondence to: AR DURÃO. E-mail: <paula.o.reis@gmail.com>.

${ }^{2}$ Pontifícia Universidade Católica do Rio Grande do Sul, Faculdade de Odontologia, Departamento de Cirurgia. Porto Alegre, RS, Brasil.

${ }^{3}$ Oral Imaging Center, OMFS-IMPATH research group, Dept Imaging \& Pathology, Faculty of Medicine, University of Leuven. Leuven, Belgium.
} 


\section{INTRODUCTION}

On lateral radiographs the sella turcica or pituitary fossa is a radiodense saddle-shaped outline of the fossa extending between the anterior and posterior clinoid processes ${ }^{1}$. It is routinely traced for cephalometric analysis ${ }^{1-3}$. Since the introduction of lateral cephalometric radiography by Broadbent ${ }^{4}$ in 1931, this radiographic technique has been widely used in orthodontics to evaluate cranial and dentofacial growth. Cephalometric analyses are based on angular and linear measurements, which might present some errors ${ }^{5}$, One of the major causes of error in cephalometric analyses occurs in landmark identification, moreover certain cephalometric points are more difficult to identify-7. The Sella (S) point, which is located at the midpoint cavity of the sella turcica ${ }^{6}$. This point is considered to be a floating landmark because it is identified by visual criteria and is not situated on a specific structure ${ }^{8}$.

Inaccurate landmark identification may lead to erroneous diagnoses and treatment plans for orthodontic cases $^{9-10}$. Some investigations, focused on the reliability of observers (clinicians, orthodontists, dental auxiliaries) to locate landmarks and make cephalometric measurements. However, no previous studies were found comparing its consistency between orthodontist and dentomaxillofacial radiologists.

The aims of this study were to determine intra- and interobserver precision on the identification of Sella (S) landmark. Additionally, Nasion (N), points A and B identification. Moreover, to determine how differences on this landmark identification could interfere with angular measurements of SNA and SNB by orthodontists and dentomaxillofacial radiologists.

\section{METHODS}

Twenty digital lateral cephalometric radiographs were retrospectively selected from the database at the Oral Imaging Centre, University of Leuven. The study was approved approved from the mandatory institutional review board. (900079). Lateral cephalograms were acquired by positioning the patients in a standard cephalometric device (Veraviewepocs 2D ${ }^{\circledR}$, J. Morita, Kyoto, Japan). The exposure values were set at $77 \mathrm{kV}$ and $7.2 \mathrm{~mA}$, with an exposure time of approximately $1.6 \mathrm{~s}$, according to each patient. The radiographs were considered to have good quality. Patients' sex, age, racial group, type of occlusion and skeletal pattern were not considered. Inclusion criteria were:

- No evidence of current orthodontic treatment;

- Digital cephalometric image were of good quality to allow landmark identification, and the ruler on the radiograph was clearly visible, allowing image calibration in the cephalometric analysis software program;

- There were no unerupted or partially erupted incisors that could have compromised landmarks identification;

- No gross skeletal asymmetry.

All images selected were then exported in TIFF format.

\section{Analysis}

A file with 20 lateral cephalometric radiographs was sent by e-mail to ten experienced observers (five orthodontists and five dentomaxillofacial radiologists [DMFR]). Each observer identified the following landmarks on each radiograph: Sella $(S)$, Point $A(A)$, Point $B(B)$ and Nasion (N), by placing a predefined red dot (Figure 1). A detailed explanation of the procedure and definitions of the 4 landmarks were given (orally and on paper) to all observers. Thus, observers followed the same landmarks definitions during the identification process. The same procedure was repeated 8 weeks after to test intraobserver variance.

After receiving all files, the main observer exported the images in TIFF format, and subsequently imported them to the computerized program for cephalometric analysis (Radiocef Studio 2; Radio Memory Ltd., Belo Horizonte, Brazil). Calibration of the actual size of each image, in millimetres, was based on measurement of a known distance $(10 \mathrm{~mm})$ between two fixed points on the LCR. Vertical and horizontal positions of each landmark were recorded in the format of $\mathrm{x}$ and $\mathrm{y}$ coordinates. Angles SNB (indicates whether the mandible is normal, prognathic, or retrognathic) and SNA (indicates whether the maxilla is normal, prognathic, or retrognathic) were measured.

The digitized landmarks' coordinates and measured angles were then copied into the Excel software (Version 2003; Microsoft, Redmond, Washington, USA).

\section{Statistical analysis}

Variation of landmark identification and angle measurements differences, mean, standard deviation and intraclass correlation coefficients (ICC) was analysed. Intra- and inter-observer reliability for each landmark in the $\mathrm{x}$ and $\mathrm{y}$ directions were calculated using ICC with a confidence interval of $95 \%$. General 
guidelines for ICC rate as excellent an ICC of $>0.90$, an ICC of $0.75-0.90$ as good, and an ICC of $<0.75$ as poor to moderate reliability ${ }^{11}$. Angles SNA and SNB were categorized according to standard values, defined by Steiner's cephalometric analysis ${ }^{10}$. Weighted kappa was calculated as well as the percentage of agreement (agreement measurements/total measurements). SNA and SNB values were observed and patient diagnosis was performed for each observation. Statistical Package for Social Sciences 20.0 for Windows (SPSS Inc., Chicago, Illinois, USA) was used for statistical analysis with statistical significance for all tests at $\alpha=0.05$.

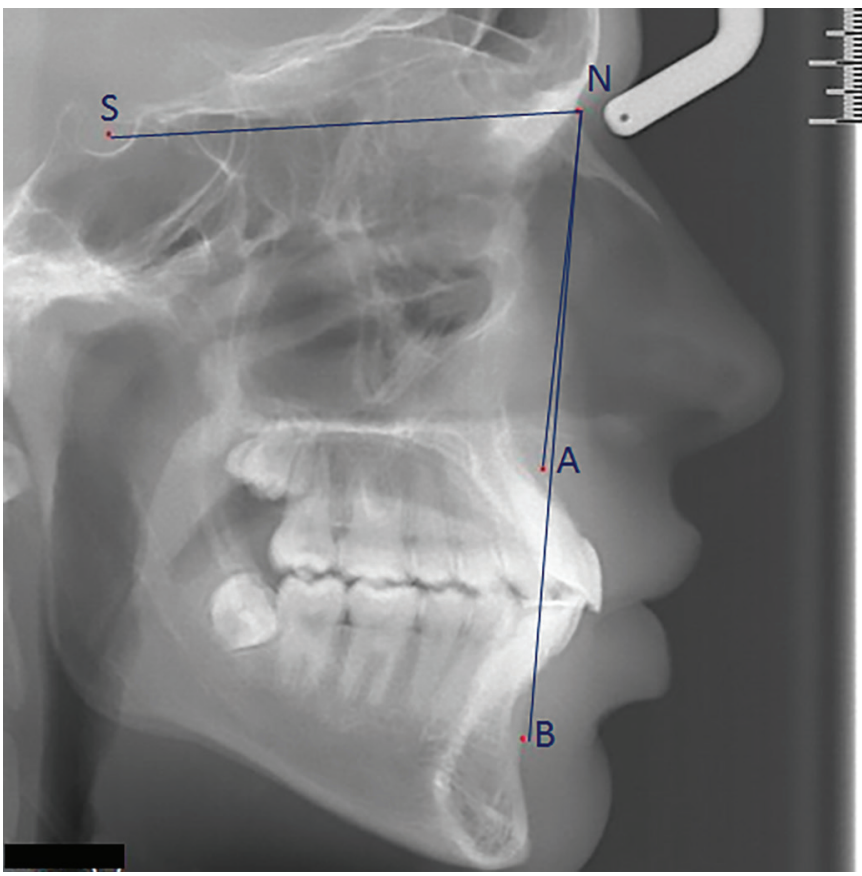

Figure 1. Lateral cephalometric radiograph showing the identified landmarks and measured angles.

\section{RESULTS}

Intra-and inter-observer reproducibility regarding identification of the horizontal and vertical components of S landmark, the ICC ranged between 0.75 and 0.90 , implying that there was a good intra-observer agreement, as well as between dentomaxillofacial radiologists and orthodontists (Table 1). Two observers obtained an ICC on the horizontal component as poor to moderate $(<0.75)$. One observer also achieved a poor-to-moderate agreement on the $S$ landmark vertical component. In general, orthodontists tended to identify the $S$ point more to the right ( $x$ direction $-0.22 \mathrm{~mm}$ ) and lower (y direction $-0.28 \mathrm{~mm}$ ) than dentomaxillofacial radiologists (Figure 2).

Intra- and inter-observer reliability of SNA and SNB angles is shown on Table 2. We found, in general, ICC values superior to 0.90, which shows an excellent agreement intra- and inter-observer for the two angles. An ICC between 0.75 and 0.90 was identified by three observers regarding angle SNA, and for one observer regarding SNB. Orthodontists tended to produce larger SNA $\left(-0.18^{\circ}\right)$ angles than dentomaxillofacial radiologists. In contrast, angle SNB tended to be lower when measured by orthodontists $\left(0.55^{\circ}\right)$ (Table 2 )

To analyse differences in landmark identification and its effect on angles SNA and SNB, a correlation method was used (Table 3).

On one hand, we found that if there were higher differences in landmark identification, the SNA angle was smaller (DMFRs: $-0.308^{\circ}$ and orthodontists: $-0.092^{\circ}$ ). On the other hand, for the SNB, we saw that if the distance between landmarks was higher, the angles tended to be higher (DMFR: $0.078^{\circ}$ and orthodontists: $-0.074^{\circ}$ ). Nevertheless, these results were not statistically significant.

Table 1. Intra- and inter-observer differences in S landmark identification (mm).

\begin{tabular}{lcccccccc}
\hline & \multicolumn{3}{c}{ Horizontal component $(\mathbf{x})$} & \multicolumn{3}{c}{ Vertical component (y) } \\
\hline & Mean & SD & ICC & [Cl 95\%] & Mean & SD & ICC & [Cl 95\%] \\
\hline DMFR & 0.08 & 0.40 & 0.984 & $0.961-0.994$ & -0.17 & 0.52 & 0.995 & $0.986-0.998$ \\
Orthodontists & 0.25 & 0.54 & 0.943 & $0.861-0.977$ & -1.09 & 1.26 & 0.961 & $0.905-0.984$ \\
DMFR-Ortho & -0.22 & 0.95 & 0.443 & $0.863-0.977$ & -0.28 & 1.47 & 0.944 & $0.865-0.978$ \\
\hline
\end{tabular}

Note: SD - standard deviation; ICC - Intraclass correlation; CI (5\% - 95\%) confidence interval. 

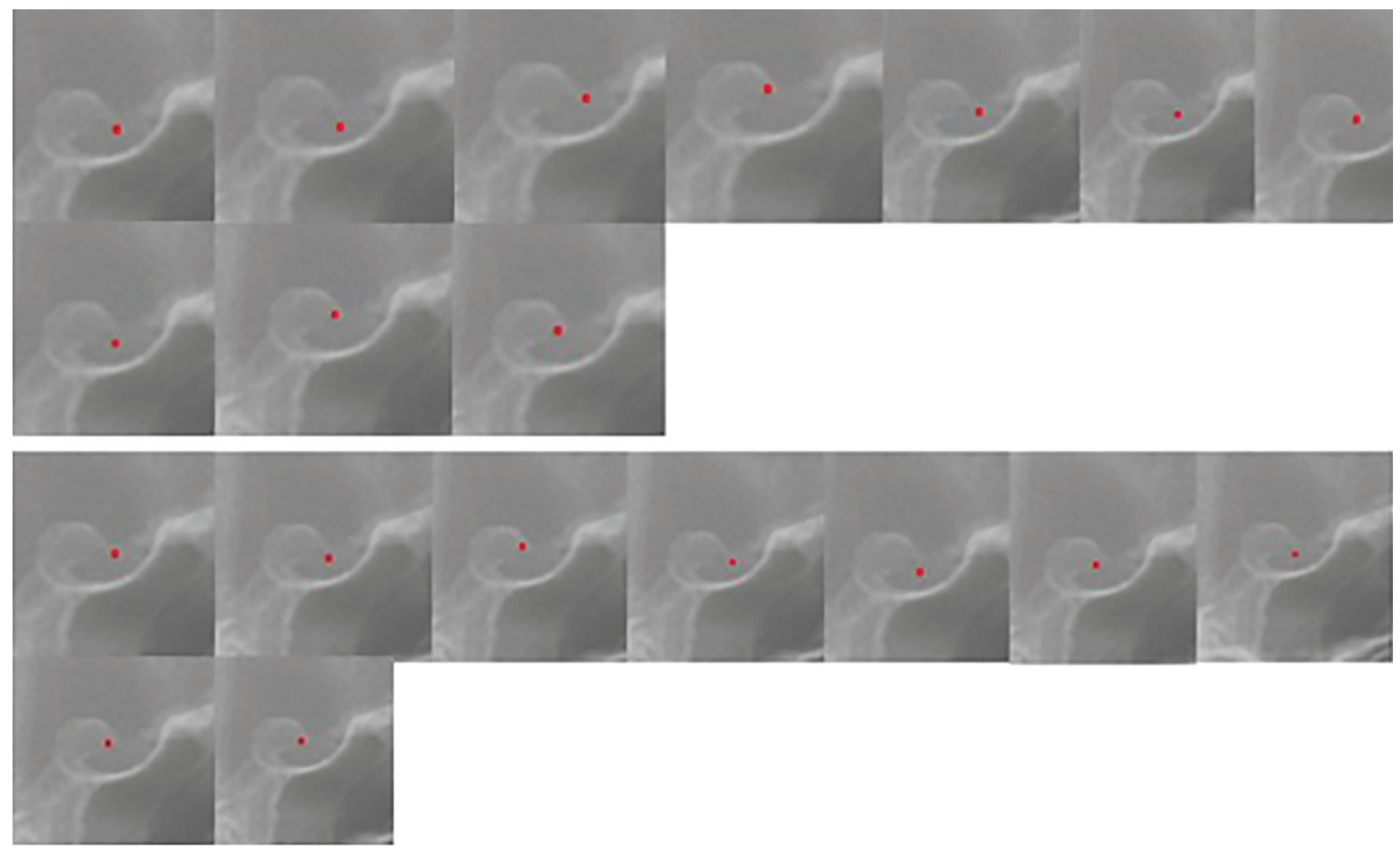

Figure 2. Example of identification of the S landmark by all observers in the same patient.

Table 2. Intra- and inter-observer differences in S landmark identification (mm).

\begin{tabular}{lcccccccc}
\hline & \multicolumn{3}{c}{ SNA } & & & SNB & \\
\hline & Mean & SD & ICC & [Cl 95\%] & Mean & SD & ICC & [Cl 95\%] \\
\hline DMFRs & -0.10 & 0.60 & 0.905 & $0.770-0.961$ & -0.01 & 0.52 & 0.976 & $0.948-0.997$ \\
Orthodontists & 0.31 & 0.70 & 0.927 & $0.824-0.970$ & 0.23 & 0.67 & 0.967 & $0.920-0.994$ \\
DMFR-Ortho & -0.18 & 0.65 & 0.977 & $0.942-0.991$ & 0.55 & 1.26 & 0.937 & $0.845-0.994$ \\
\hline
\end{tabular}

Note: SD - standard deviation; ICC - Intraclass correlation; CI (5\% - 95\%) confidence interval

Table 3. Correlation between point $S$ identification of and its effect on SNA and SNB angles.

\begin{tabular}{lcccc}
\hline & \multicolumn{2}{c}{ SNA } & \multicolumn{2}{c}{ SNB } \\
\hline & $\boldsymbol{r}$ & $\boldsymbol{p}$ & $\mathbf{R}$ & $\boldsymbol{p}$ \\
\hline DMFRs & -0.308 & 0.186 & 0.078 & 0.743 \\
Orthodontists & -0.092 & 0.699 & -0.074 & 0.075 \\
\hline
\end{tabular}

Note: r- Pearson correlation; $p-0.05$.

It was observed that in a number of cases, maxilla and mandibular positions diagnosis was changed due to differences in SNA and SNB angles (Table 4). SNA angle revealed changes between $0.50^{\circ}$ and $7.92^{\circ}$, while the minimum difference on SNB was of $0.31^{\circ}$ and the major was of $8.42^{\circ}$.

Amongst orthodontists, the variability of these angles was different changing patients' diagnosis 25 times, regarding maxillary position (SNA angle). Mostly, the position of the maxilla was changed from normal to retruded. Only in one case diagnosis was modified from protruded to retruded maxilla. 
A slightly higher percentage of agreement was evident for orthodontists (70\%) in relation to dentomaxillofacial radiologists (55\%).

When measured by dentomaxillofacial radiologists, angle SNB was changed in six patients. The percentage of agreement for the SNB was equal in both groups (80\%). The value in which the SNB is considered normal was changed by orthodontists 23 times. Major differences were noted between diagnoses of normal to retruded mandible. The diagnosis was modified from retruded to protruded mandible only in one case.

Table 4. Number of cases ( $n$ ) in which diagnosis was changed, regarding the SNA and SNB standard values, according to each observer. Minimum and maximum degree variations are indicated.

\begin{tabular}{|c|c|c|c|c|c|c|c|c|}
\hline & SNA (n) & Minimum (o) & & Maximum (o) & SNB (n) & Minimum (o) & & Maximum (o) \\
\hline Observer 1 & 4 & 1.33 & & 6.83 & 1 & & 1.96 & \\
\hline Observer 2 & 1 & & 1.62 & & 3 & 0.31 & & 5.21 \\
\hline Observer 3 & 6 & 0.50 & & 5.99 & 1 & & 0.90 & \\
\hline Observer 4 & 6 & 1.07 & & 6.07 & 1 & & 6.00 & \\
\hline Observer 5 & 0 & & - & & 0 & & - & \\
\hline Observer 6 & 1 & 1.31 & & 7.24 & 7 & 2.45 & & 8.42 \\
\hline Observer 7 & 5 & 0.64 & & 7.92 & 4 & 0.40 & & 8.71 \\
\hline Observer 8 & 6 & 1.01 & & 4.07 & 2 & 1.01 & & 2.73 \\
\hline Observer 9 & 8 & 1.58 & & 6.00 & 3 & 1.21 & & 2.39 \\
\hline Observer 10 & 5 & 1.81 & & 4.95 & 7 & 1.07 & & 5.55 \\
\hline
\end{tabular}

\section{DISCUSSION}

Inaccurate landmark identification is one the most frequent source of error in cephalometric analysis ${ }^{12-14}$. Also, observers training experience and background may lead to errors ${ }^{7,15-17}$. All orthodontists involved in this study had the same background experience, since they were trained at the same institution. Some differences in background education existed between dentomaxillofacial radiologists. To eliminate possible errors that could arise from this, a detailed explanation of landmark's definition was given by the main author.

SN plane represents the anterior cranial base. Variability in S landmark identification may modify angles SNA and SNB. On our previous study, we found that landmark $S$ had low intra- and inter-observer variability, which was consistent with other studies $7,13,18$. Depending on the error magnitude, landmarks identification, patient's diagnosis can change. We studied how an imprecise identification of point $\mathrm{S}$ could lead to different SNA and SNB angles. According to some authors, landmark identification errors inferior to $1 \mathrm{~mm}$ are considered accurate ${ }^{13,19}$. Other authors believe that a difference of $2 \mathrm{~mm}$ is considered acceptable and does not have any influence in orthodontic diagnosis and treatment plan ${ }^{17,20}$ Reliability of S landmark identification was relatively low, presenting a deviation of $-0.22 \mathrm{~mm}$ in the $x$ direction and of $0.28 \mathrm{~mm}$ in the $y$ direction. Some cephalometric landmarks are more reliable in either the horizontal or vertical plane ${ }^{21}$. We had previously revealed a low variability of the S landmark. In that previous study, we had suggested that, with a small range of variation (> $2 \mathrm{~mm}$ ) in landmark identification, patient diagnosis could change. Nevertheless, in general, in the present study, intra- and inter-observer agreement for the SNA and SNB angles was good (ICC 0.75-0.90). Our results showed a relatively high standard deviation, this could be justified by the sample heterogeneity. It consisted of 20 patients of both genders, and ages between 10 and 18 years.

Steiner ${ }^{22}$ used angles SNA and SNB for patients' diagnoses. We revealed that minor changes in $S$ landmark identification could change both SNA and SNB classifications. Dentomaxillofacial radiologists, showed differences in patient's diagnosis in 17 cases out of 100 observations. Regarding SNB, mandible position diagnosis was changed in 5 cases. Overall, a higher variability was found amongst orthodontists. Between orthodontists, maxillary position diagnosis was changed in 25 cases, 
while mandible's position diagnosis was changed in 23 cases. Larger variations were found in both groups on the SNA angle. This could happen due to point A identification, which is more difficult to identify than point B. We should remember that "standard" values for these two angles were defined by a small number of individuals that were supposed to be representative of a population. Due to the inflexible interval given for these angles, patients who deviate just slightly from the standard value may have an erroneous diagnosis. We suggested that changes of $0.50^{\circ}$ in SNA and of $0.31^{\circ}$ in SNB could alter patient's diagnosis concerning mandible and the maxilla positions. An incorrect diagnosis may lead to erroneous orthodontic treatment. To perform a diagnosis and treatment plan in orthodontics, many variables are taken into account; therefore, each step of the process should be performed with maximum accuracy. The results of this study question the validity of cephalometric analysis in orthodontics, since a small variation on these landmarks' identification can lead to different diagnosis and, thus, different treatment plans.

In the present study, the selected radiographs had good technical and imaging quality. In this way, the inaccuracy observed on some landmark identification could be related to examiners' performance on identification of cephalometric points.

The results found can explain the variability on, the identification of landmark, in relation to two dental specializations. LCR used presented high quality standards, so discrepancy on landmark identification between professionals of these two dental specialties could be justified by the superimposed anatomical structures present in 2D LCR. This can be minimized since the introduction of 3D imaging, which eliminates overlapping of anatomical structures and magnification ${ }^{6}$.

Lau et al. ${ }^{20}$ analyzed inter-examiner variation on landmark identification by orthodontic and oral and maxillofacial surgery students. The results showed a high rate of errors, both in the identification of points as in the angular and linear measurements derived from these. These authors suggested that individual perception might be the reason.

Different graphic radiographic can occur due to the lack of precision on landmark definition or inadequate verification of the bony structures ${ }^{12,23}$.

Inter-observer errors, are greater than intraobserver faults ${ }^{24}$. Intra-observer errors are related to educational level and experience ${ }^{20}$.
Errors related to landmark identification, occur among other factors due to anatomical variability of landmark location, patient's head position variations, image magnification, difficulties that arise a 2-dimensional image representing a 3-dimensional structure and also owing to overlapping of bilateral structures ${ }^{23,25-28}$. Interobserver inconsistencies in landmark identification and tracing errors are also major sources of discrepancies ${ }^{29}$. A potential source of error in landmark identification is associated with anatomic complexity of radiographic images and difficulty in delineating a landmark on a curved anatomical boundary ${ }^{25}$. Orthodontists tended to identify the $S$ point lower and more to the right than dentomaxillofacial radiologists, which may be explained by the variations in the size and clinoid process morphology. Also, the anterior clinoid process are larger and more variable. Radiographic anatomy knowledge is of extreme importance ${ }^{1-3}$. Individual morphologic variations caused by growth may affect landmark recognition.

It may be expected that digital imaging would reduce landmark identification errors. Additionally, individual conception of landmark definition and its perception can affect landmark location ${ }^{7}$. However, it is also interesting to note that skeletal morphology extreme variations do not interfere with accuracy of cephalometric evaluation.

Several authors, investigated intra- and interobserver variability in landmark identification ${ }^{19}$. Gravely and Benzies ${ }^{13}$ concluded that dental auxiliaries showed a greater variability in point identification compared to orthodontists. Standardization of observers prior to landmark registration tended to decrease variability among operators. In this study, we compared the reliability of 2 dental specialties to identify 2 D cephalometric landmarks. No previous studies evaluated its consistency amongst dentomaxillofacial radiologists and orthodontists. We used the talents of orthodontists and dentomaxillofacial radiologists to evaluate intraand inter-observer identification of landmarks Sella (S), Nasion (N), point $A$ and $B$ ) and evaluate how it could interfere with SNS and SNB measurements.

\section{CONCLUSION}

In conclusion, Sella landmark identification tended to have a better agreement amongst dentomaxillofacial radiologists. Orthodontists, however, showed a larger 
variability in S identification and, consequently, the SNA and SNB angles drifted significantly. Small modifications in identifications of the $S, N, A$ and $B$ points may lead to differences in angles SNA and SNB. Therefore, patient diagnosis and treatment can vary. More differences existed regarding SNA than SNB. Further studies on a larger patient sample with inclusion of more borderline cases may be needed to determine the real clinical impact on treatment planning.

\section{REFERENCES}

1. Abdel-Kader HM. Sella turcica bridges in orthodontic and orthognathic surgery patients. A retrospective cephalometric study. Aust Orthod J. 2007;23(1):30-35

2. Jones RM, Faqir A, Millett DT, Moos KF, McHugh S. Bridging and dimensions of sella turcica in subjects treated by surgicalorthodontic means or orthodontics only. Angle Orthod 2005;75:714-718. doi: 10.1043/0003-3219(2005)75[714:BA DOST]2.0.CO;2

3. Kolagi S, Herur A, Patil G, Rairam GB. Complete Sella turcica bridges prevalence and dimensions. J Anat Soc India. 2011;60(1):22-5.

4. Broadbent $\mathrm{BH}$. A new x-ray technique and its application to orthodontia. Angle Orthod. 1931;1:45-66.

5. Hussels W, Nanda RS. Analysis of factors affecting angle ANB. Am J Orthod. 1984;85(5):411-23. doi: 10.1016/00029416(84)90162-3

6. Proffit WR, Fields HW, Sarver DM. Contemporary orthodontics. 4th ed. Mosby Elsevier; 2006

7. Riedel RA. The relation of maxillary structures to cranium in malocclusion and in normal occlusion. Angle Orthod. $1952 ; 22: 142-5$

8. Oktay H. A comparison of ANB, WITS, AF-BF, and APDI measurements. Am J Orthod Dentofacial Orthop. 1991;99:122128. doi: 10.1016/0889-5406(91)70114-C

9. Tng TT, Chan T, Hägg U, Cooke M. Validity of cephalometric landmarks. An experimental study. Eur J Orthod. 1994;16:11020. doi: 10.1093/ejo/16.2.110

10. Chen YJ, Chen SK, Huang HW, Yao CC, Chang HF. Reliability of landmark identification in cephalometric radiography acquired by a storage phosphor imaging system. Dentomaxillofac Radiol. 2004;33(5):301-6. doi: 10.1259/dmfr/85147715

11. Kamoen A, Dermaut $L$, Verbeeck $R$. The clinical significance of error measurement in the interpretation of treatment results. Eur J Orthod. 2001;23(5):569-578. doi: 10.1093/ejo/23.5.569

\section{Collaborators}

AR DURÃO, preparation of the research project and implementation of experimental part and writing of the discussion and conclusions. A MOROSOLLI, preparation of the discussion and conclusions and verification of the final structuring of the manuscript. CC DIAS, tabulation and statistical analysis of the results. AP FERREIRA, guidance of the research project and verification of the results. R JACOBS, co-Orientation of the research project and assistance and verification of the results.

12. Kvam $E$, Krogstad $O$. Variability in tracings of lateral head plates for diagnostic orthodontic purposes. A methodology study. Acta Odontol Scand. 1969;27:359-369.

13. Gravely JF, Benzies PM. The clinical significance of tracing error in cephalometry. Br J Orthod. 1974;1:95-101.

14. Shrout, PE, Fleiss JL. Intraclass correlations: Uses in assessing rater reliability. Psychological Bull. 1979;86(2):420-8. doi: 10.1037/0033-2909.86.2.420

15. Miloro M, Borba AM, Ribeiro-Junior $O$, Naclério-Homem MG, Jungner $\mathrm{M}$. Is there consistency in cephalometric landmark identification amongst oral and maxillofacial surgeons? Int J Oral Maxillofac Surg. 2014;43(4):445-453. doi: 10.1016/j. ijom.2013.08.007

16. Oz $U$, Orhan $\mathrm{K}$, Abe N. Comparison of linear and angular measurements using two dimensional conventional methods and three-dimensional cone beam CT images reconstructed from a volumetric rendering program in vivo. Dentomaxillofac Radiol. 2011;40(8):492-500. doi: 10.1259/dmfr/15644321

17. Richardson A. A comparison of traditional and computerized methods of cephalometric analysis. Eur J Orthod. 1981;3:1520. doi: 10.1093/ejo/3.1.15

18. Lau PY, Cooke MS, Hagg U. Effect of training and experience on cephalometric measurement errors on surgical patients. Int J Adult Orthod Orthognath Surg. 1997;12:204-13.

19. Baumrind $S$, Frantz RC. The reliability of head film measurements. 1. Landmark identification. Am J Orthod. 1971;60(2):111-27. doi: 10.1016/0002-9416(71)90028-5

20. Steiner CC. Cephalometrics for you and me. Am J Orthod. 1953;39(10):729-55. doi: 10.1016/0002-9416(53)90082-7

21. Houston WJB, Maher RE, McElroy D, Sherriff M. Sources of error in measurements from cephalometric radiographs. Eur J Orthod. 1986;8(3):149-51. doi: 10.1093/ejo/8.3.149

22. McClure SR, Sadowsky PL, Ferreira A, Jacobson A. Reliability of digital versus conventional cephalometric radiology: a comparative evaluation of landmark identification error. Seminar Orthod. 2005;11(2):98-110. doi: 10.1053/j. sodo.2005.04.002 
23. Grauer D, Cevidanes LSH, Styner MA, Heulfe I, Harmon ET, Zhuf $\mathrm{H}$, et al. Accuracy and landmark error calculation using cone-beam computed tomography-generated cephalograms. Angle Orthod. 2010;80(2):286-94. doi: 10.2319/030909135.1

24. Sekiguchi T, Savara BS. Variability of cephalometric iandmarks used for face growth studies. Am J Orthod. 1972;61(2):60318. doi: 10.1016/0002-9416(72)90109-1

25. Savara B, Takeuchi Y. Anatomic location of cephalometric landmarks on the sphenoid and temporal bones. Angle Orthod. 1979;49(2):141-9. doi: 10.1043/0003-3219(1979)049<0141:ALOCLO>2.0.CO;2

26. Santoro M, Jarjoura K, Cangialosi T J. Accuracy of digital and analogue cephalometric measurements assessed with the sandwich technique. Am J Orthod Dentofac Orthop. 2006;129(3):345-51. doi: 10.1016/j.ajodo.2005.12.010

27. Savage AW, Showfety KJ, Yancey J. Repeated measures analysis of geometrically constructed and directly determined cephalometric points. Am J Orthod Dentofac Orthop. 1987;9(4):295-9. doi: 10.1016/0889-5406(87)90169-7
28. Midtgard J, Björk G, Linder-Aronson S. Reproducibility of cephalometric landmarks and errors of measurements of cephalometric cranial distances. Angle Orthod. 1974; 44(1): 56-61. doi: 10.1043/0003-3219(1974)044<0056:ROCLAE $>2$ $0 . \mathrm{CO} ; 2$

29. Wahl N. Orthodontics in 3 millennia. Chapter 7: Facial analysis before the advent of the cephalometer. Am J Orthod Dentofacial Orthop. 2006;129(2):293-8. doi: 10.1016/j. ajodo.2005.12.011
Received on: 9/3/2016

Final version resubmitted on: 20/5/2016

Approved on: 4/6/2016 